\title{
Development and validation of stability- indicating RP-HPLC method for the simultaneous determination of ertugliflozin pidolate and metformin hydrochloride in bulk and tablets
}

\author{
K. Sravana Kumari i(i) and Sailaja Bandhakavi
}

\begin{abstract}
Background: In the present study, an improved simple, specific, rapid, sensitive, precise, accurate and stabilityindicating RP-HPLC method for the simultaneous estimation of ertugliflozin pidolate and metformin hydrochloride in bulk and tablets was developed and validated. The separation of ertugliflozin pidolate and metformin $\mathrm{HCl}$ was achieved isocratically on Kromasil C18 column $(150 \mathrm{~mm} \times 4.6 \mathrm{~mm}, 5 \mu \mathrm{m})$ using $0.1 \%$ ortho-phosphoric acid buffer ( $\mathrm{pH}$ 2.7):acetonitrile $(65: 35 \% \mathrm{~V} / \mathrm{v})$ as mobile phase, pumped at a flow rate of $1 \mathrm{ml} / \mathrm{min}$ and column temperature of $30 \pm 2^{\circ} \mathrm{C}$. HPLC grade water:ACN (1:1) was used as diluent. About $10 \mu \mathrm{l}$ of standard solution of the drugs was injected, and the eluted analytes were detected at $224 \mathrm{~nm}$.

Results: Metformin $\mathrm{HCl}$ was eluted at $2.170 \mathrm{~min}$ and ertugliflozin pidolate at $2.929 \mathrm{~min}$ with a run time of $5.0 \mathrm{~min}$. Linearity of the developed method was observed in the concentration range of $0.9375-5.625 \mu \mathrm{g} / \mathrm{ml}$ for ertugliflozin pidolate and $62.5-375 \mathrm{\mu g} / \mathrm{ml}$ for metformin $\mathrm{HCl}$ with a correlation coefficient of 0.999 for both the drugs. LOD for ertugliflozin pidolate and metformin $\mathrm{HCl}$ were $0.025 \mu \mathrm{g} / \mathrm{ml}$ and $0.87 \mu \mathrm{g} / \mathrm{ml}$ respectively. $\mathrm{LOQ}$ for ertugliflozin pidolate and metformin $\mathrm{HCl}$ were $0.076 \mu \mathrm{g} / \mathrm{ml}$ and $2.63 \mu \mathrm{g} / \mathrm{ml}$.

Conclusion: The developed RP-HPLC method for the simultaneous estimation of ertugliflozin pidolate and metformin $\mathrm{HCl}$ in bulk and tablets was simple, rapid, sensitive, accurate, precise, linear, and stability indicating. Hence, the developed method could be used for the routine quality control of the drugs in bulk and tablets.
\end{abstract}

Keywords: Stability-indicating RP-HPLC, Ertugliflozin pidolate, Metformin $\mathrm{HCl}$, Kromasil C18 column

\section{Background}

Globally, about 463 million people are suffering from type-2 diabetes mellitus [1] which is manifested by polydipsia, polyuria, and polyphagia and requires a lifetime treatment with antidiabetic drugs [2]. The treatment goals involve the achievement of glycemic control and reducing the diabetes-associated cardiovascular risk.

\footnotetext{
* Correspondence: sravanipharma117@gmail.com

Institute of Pharmaceutical Technology, Sri Padmavati MahilaVisvavidyalayam, Tirupati, A.P 517502, India
}

\section{Springer Open}

Patients suffering from recent onset of diabetes are treated with metformin, an insulin sensitizer. The risk of hypoglycemia is insignificant with metformin and drug interactions are less making it a highly safe and acceptable first-line of drug for the treatment of early type-2 diabetes mellitus [3].

The pathogenesis of type- 2 diabetes mellitus is multiplex, involving several organs, and treatments using a combination of drugs with different mechanisms of action effectively controls the plasma glucose levels [4]. Sodium glucose co-transporter type-2 (SGLT-2) inhibitors (c) The Author(s). 2020 Open Access This article is licensed under a Creative Commons Attribution 4.0 International License, which permits use, sharing, adaptation, distribution and reproduction in any medium or format, as long as you give appropriate credit to the original author(s) and the source, provide a link to the Creative Commons licence, and indicate if changes were made. The images or other third party material in this article are included in the article's Creative Commons licence, unless indicated otherwise in a credit line to the material. If material is not included in the article's Creative Commons licence and your intended use is not permitted by statutory regulation or exceeds the permitted use, you will need to obtain permission directly from the copyright holder. To view a copy of this licence, visit http://creativecommons.org/licenses/by/4.0/. 
are the new option for the treatment of type- 2 diabetes mellitus. These agents act by inhibiting SGLT-2 transporter in the kidneys, thereby promoting the excretion of glucose in urine and reducing the plasma glucose levels [5]. Ertugliflozin pidolate, a SGLT-2 inhibitor, is used in the treatment of Type-2 diabetes mellitus with a pKa of 11.98 and $\log \mathrm{P}$ of 2.21 . The drug is soluble in ethanol, sparingly soluble in ethyl acetate and acetonitrile, and very slightly soluble in water $[6,7]$. Metformin hydrochloride is a biguanide anti-diabetic with a $\mathrm{pKa}$ of 12.33 and $\log \mathrm{P}$ of -0.92 . It is freely soluble in water, sparingly soluble in alcohol, and practically insoluble in acetone and dichloromethane $[6,8]$. The structures of ertugliflozin pidolate and metformin $\mathrm{HCl}$ are shown in Figs. 1 and 2.

Ertugliflozin pidolate and metformin hydrochloride in combination efficiently reduce the elevated $\mathrm{HbA}_{1 \mathrm{c}}$ levels in type-2 diabetic patients [6]. A simultaneous method development deals with the analysis of a combination of drugs and is useful for the analysis of two or more drugs of a formulation without their separation. The method is rapid and cost-effective as the reagents used are common for the analysis of the drugs [9]. Extensive literature study revealed that two methods were reported for the simultaneous estimation of both the selected drugs in bulk and formulations by RP-HPLC $[10,11]$. In the present study, an improved stability-indicating RP-HPLC method for the simultaneous estimation of ertugliflozin pidolate (ERTU) and metformin $\mathrm{HCl}$ (MET) in bulk and tablets was designed to develop and validate.

\section{Methods}

Reference standard of ertugliflozin pidolate was obtained as gift sample from Ajanta Pharma, Mumbai and metformin $\mathrm{HCl}$ from Laurus Labs, Hyderabad. Water, methanol, acetonitrile of HPLC grade, and ortho phosphoric acid of analytical reagent grade from Merck, Mumbai were used for the present study. The commercially available ertugliflozin pidolate and metformin $\mathrm{HCl}$ tablet formulation Segluromet (Merck Sharp \& Dohme Corp) with a label claim of ERTU $7.5 \mathrm{mg}$, MET $500 \mathrm{mg}$ was used.

\section{Instrumentation}

Waters HPLC (Separation module 2965) chromatographic system equipped with PDA-detector 2487 with Empower-2 software, Shimadzu digital weighing balance (ATX 224), Bio-Technics ultra-Sonicator (BTI-48), Elico $\mathrm{pH}$ meter (LI 120), and Millipore vacuum filter pump (XI 5522050) were used for the development of the method. A $0.22-\mu \mathrm{m}$ Nylon filter and a $0.45-\mu \mathrm{m}$ Polytetrafluoroethylene (PTFE) filter of Merck Millipore were used for filtration.

\section{Chromatographic conditions}

The separation of ertugliflozin pidolate and metformin $\mathrm{HCl}$ was achieved using Kromasil C18 column (150 $\mathrm{mm} \times 4.6 \mathrm{~mm}, 5 \mu \mathrm{m}), 0.1 \%$ ortho-phosphoric acid buffer $(\mathrm{pH}$ 2.7):acetonitrile $(65: 35 \%, v / v)$, flow rate of $1 \mathrm{ml} / \mathrm{min}$, an injection volume of $10 \mu \mathrm{l}$, at a $\lambda \max$ of $224 \mathrm{~nm}$, and column temperature $30 \pm 2{ }^{\circ} \mathrm{C}$ using HPLC grade water: ACN (1:1) as diluent.
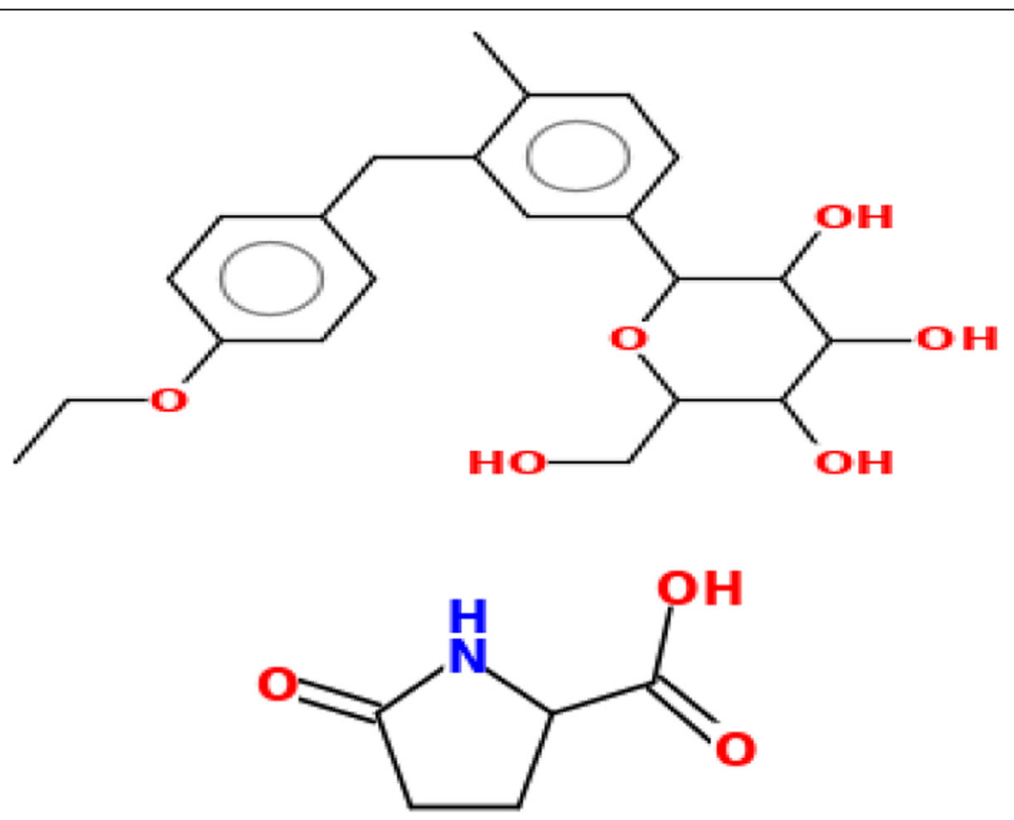

Fig. 1 Structure of ERTU 


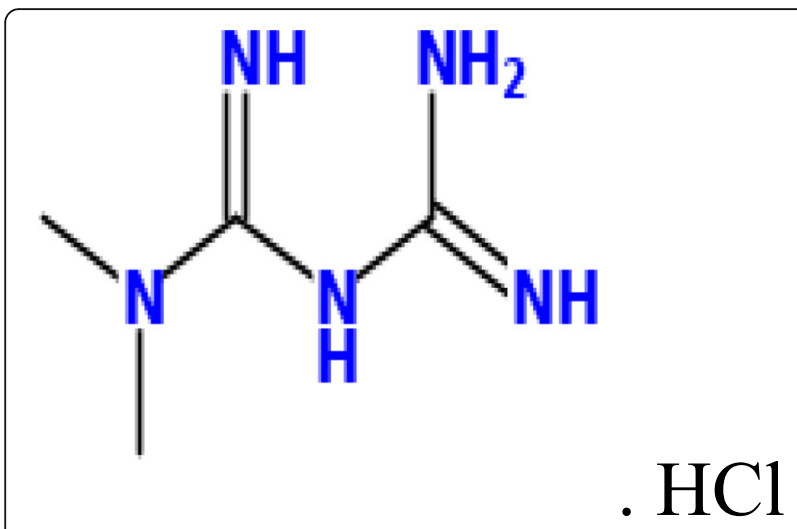

Fig. 2 Structure of MET

Preparation of $0.1 \%$ ortho-phosphoric acid buffer $(\mathrm{pH} 2.7)$ About $1 \mathrm{ml}$ of ortho-phosphoric acid was diluted to 11 with HPLC grade water in a $1-\mathrm{L}$ volumetric flask. The solution was degassed by ultra-sonicating for $5 \mathrm{~min}$, and the resultant solution was filtered through a $0.45-\mu \mathrm{m}$ PTFE filter. The $\mathrm{pH}$ of the prepared buffer was checked using a $\mathrm{pH}$ meter.

\section{Preparation of standard solution of ERTU and MET}

Standard stock solution was prepared by accurately weighing and transferring $3.75 \mathrm{mg}$ of ERTU and $250 \mathrm{mg}$ of MET bulk drugs into a 100-ml volumetric flask. About $10 \mathrm{ml}$ of the diluent was added, and the solution was ultra-sonicated for $10 \mathrm{~min}$ to dissolve the drugs completely. The final volume was made up with HPLC grade water:ACN (1:1), and the solution was filtered through a $0.45-\mu \mathrm{m}$ PTFE filter (ERTU $(37.5 \mu \mathrm{g} / \mathrm{ml})$ and $\operatorname{MET}(2500 \mu \mathrm{g} / \mathrm{ml}))$.

Accurately, $1 \mathrm{ml}$ of standard stock solution was transferred into a $10-\mathrm{ml}$ volumetric flask, and the volume was made up with the diluent to prepare working standard solution (ERTU $(3.75 \mu \mathrm{g} / \mathrm{ml})$ and MET $(250 \mu \mathrm{g} / \mathrm{ml}))$.

\section{Preparation of sample solution of ERTU and MET}

About 20 tablets of Segluromet were weighed and powdered finely. Tablet powder equivalent to $3.75 \mathrm{mg}$ of ERTU and $250 \mathrm{mg}$ of MET was weighed and transferred into a $100-\mathrm{ml}$ volumetric flask and dissolved completely by sonicating for $25 \mathrm{~min}$ using $10 \mathrm{ml}$ of the diluent. The final volume was made up with the diluent and filtered through $0.45-\mu \mathrm{m}$ PTFE filter (Stock solution: ERTU $(37.5 \mu \mathrm{g} / \mathrm{ml})$ and MET $(2500 \mu \mathrm{g} / \mathrm{ml}))$.

Accurately $1 \mathrm{ml}$ of sample stock solution was diluted to $10 \mathrm{ml}$ in a $10-\mathrm{ml}$ volumetric flask with the diluent (Working sample solution: ERTU $(3.75 \mu \mathrm{g} / \mathrm{ml})$ and MET $(250 \mu \mathrm{g} / \mathrm{ml}))$.

\section{Validation [12]}

The developed RP-HPLC method was validated as per ICH guidelines. The parameters validated are Specificity, Forced degradation studies, Accuracy, Precision (Intraday precision, Inter-day precision), Linearity, Limit of Detection (LOD), Limit of quantitation (LOQ), Solution stability, Robustness, and System suitability parameters.

\section{Specificity}

Specificity of the developed RP-HPLC method was established by injecting $10 \mu \mathrm{l}$ each of the blank, working standard, and sample solutions.

\section{Forced degradation studies [13-15]}

The stability of the developed method was established by performing forced degradation studies of the drug in the presence of acid, alkali, $\mathrm{H}_{2} \mathrm{O}_{2}$, temperature, UV light, and HPLC grade water.

\section{Acid degradation}

Degradation under acidic condition was evaluated by treating $1 \mathrm{ml}$ of standard stock solution of ERTU and MET with $1 \mathrm{ml}$ of $2 \mathrm{~N} \mathrm{HCl}$ and refluxed for $30 \mathrm{~min}$ at $60 \pm 2{ }^{\circ} \mathrm{C}$. The resulting solution was diluted to $10 \mathrm{ml}$ with the diluent.

\section{Alkali degradation}

Under alkaline conditions, degradation was studied by refluxing $1 \mathrm{ml}$ of standard stock solution of ERTU and MET with $1 \mathrm{ml}$ of $2 \mathrm{~N} \mathrm{NaOH}$ for $30 \mathrm{~min}$ at $60 \pm 2{ }^{\circ} \mathrm{C}$. The stressed solution was made up to $10 \mathrm{ml}$ with the diluent.

\section{Oxidative degradation}

About $1 \mathrm{ml}$ of standard stock solution of ERTU and MET was subjected to oxidative degradation by refluxing with $20 \% v / v \mathrm{H}_{2} \mathrm{O}_{2}$ in a 10-ml volumetric flask for 30 min at $60 \pm 2{ }^{\circ} \mathrm{C}$ and made up with the diluent.

\section{Thermal degradation}

Thermal stability of the drugs was evaluated by placing the standard stock solution in the oven at $105 \pm 2{ }^{\circ} \mathrm{C}$ for $6 \mathrm{~h}$. About $1 \mathrm{ml}$ of the stressed solution was diluted to $10 \mathrm{ml}$ with the diluent.

\section{Photolytic degradation}

Photolytic degradation was studied by exposing the standard solution of ERTU and MET to UV light in the UV chamber for 7 days. The resulting stressed solution was diluted to $10 \mathrm{ml}$ with the diluent.

\section{Neutral degradation}

Neutral degradation was carried out by refluxing $1 \mathrm{ml}$ of standard stock solution with $1 \mathrm{ml}$ of HPLC grade water 
Table 1 Preliminary trial runs

\begin{tabular}{|c|c|c|c|}
\hline Trial & Column & Mobile phase & Observation \\
\hline 1 & $\begin{array}{l}\text { BDS C18 } \\
(250 \mathrm{~mm} \times 4.6 \mathrm{~mm}, 5 \mu \mathrm{m})\end{array}$ & $\begin{array}{l}\text { Methanol: } \\
0.1 \% \text { OPA } \\
\text { (40:60) }\end{array}$ & Only MET was eluted with less theoretical plates \\
\hline 2 & $\begin{array}{l}\text { BDS C18 } \\
(250 \mathrm{~mm} \times 4.6 \mathrm{~mm}, 5 \mu \mathrm{m})\end{array}$ & $\begin{array}{l}\mathrm{ACN}: \mathrm{KH}_{2} \mathrm{PO}_{4} \\
(40: 60)\end{array}$ & Only MET was eluted \\
\hline 3 & $\begin{array}{l}\text { Agilent C18 } \\
(250 \mathrm{~mm} \times 4.6 \mathrm{~mm}, 5 \mu \mathrm{m})\end{array}$ & $\begin{array}{l}\text { ACN: } 0.1 \% \text { OPA } \\
(60: 40)\end{array}$ & Peak symmetry of both the peaks was good but with increased retention time \\
\hline 4 & $\begin{array}{l}\text { Kromasil C18 } \\
(150 \mathrm{~mm} \times 4.6 \mathrm{~mm}, 5 \mu \mathrm{m})\end{array}$ & $\begin{array}{l}\text { ACN: } 0.1 \% \text { OPA } \\
(50: 50)\end{array}$ & Peak symmetry was good but MET eluted at $1.6 \mathrm{~min}$ \\
\hline 5 & $\begin{array}{l}\text { Kromasil C18 } \\
(150 \mathrm{~mm} \times 4.6 \mathrm{~mm}, 5 \mu \mathrm{m})\end{array}$ & $\begin{array}{l}\text { ACN: } 0.1 \% \text { OPA } \\
(65: 35)\end{array}$ & Peak symmetry was good with system suitability parameters in limits \\
\hline
\end{tabular}

in a 10 -ml volumetric flask at $60 \pm 2{ }^{\circ} \mathrm{C}$ for $6 \mathrm{~h}$. The volume was made up with the diluent.

About $10 \mu \mathrm{l}$ of each of the solutions exposed to different stress conditions were injected separately into the column, and the chromatograms were recorded to evaluate the stability of the drugs.

\section{Accuracy}

Accuracy was established by injecting about $10 \mu \mathrm{l}$ of ERTU and MET at 80, 100, and 120\% levels into the column, and the procedure was repeated thrice. Mean percent recovery of three levels was determined using the peak areas at each level.

\section{Precision}

Precision of the optimized method was determined by injecting six samples of working standard solution of ERTU and MET into the column on the same day for intra-day precision and on two continuous days for inter-day precision; \% RSD was calculated.

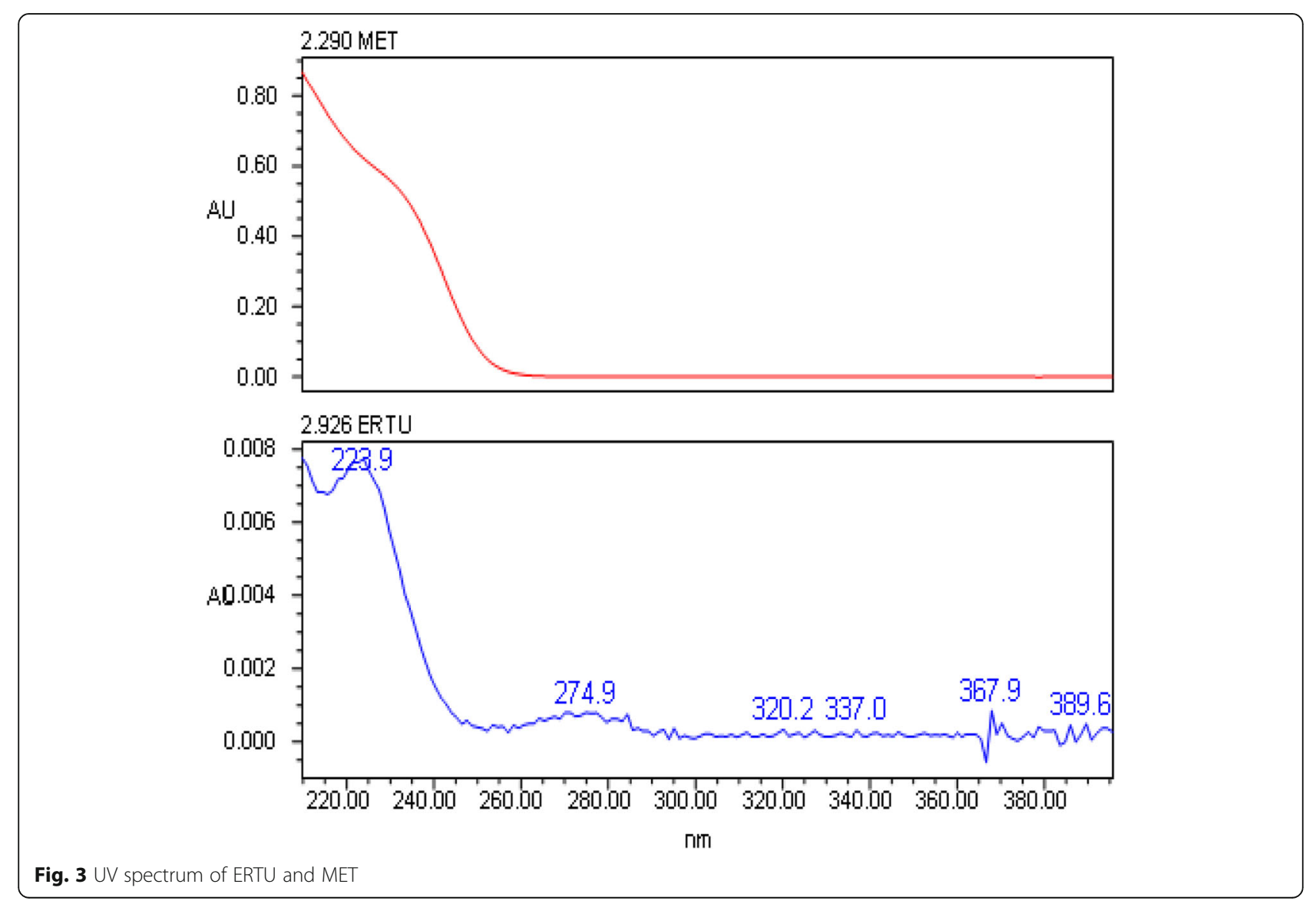




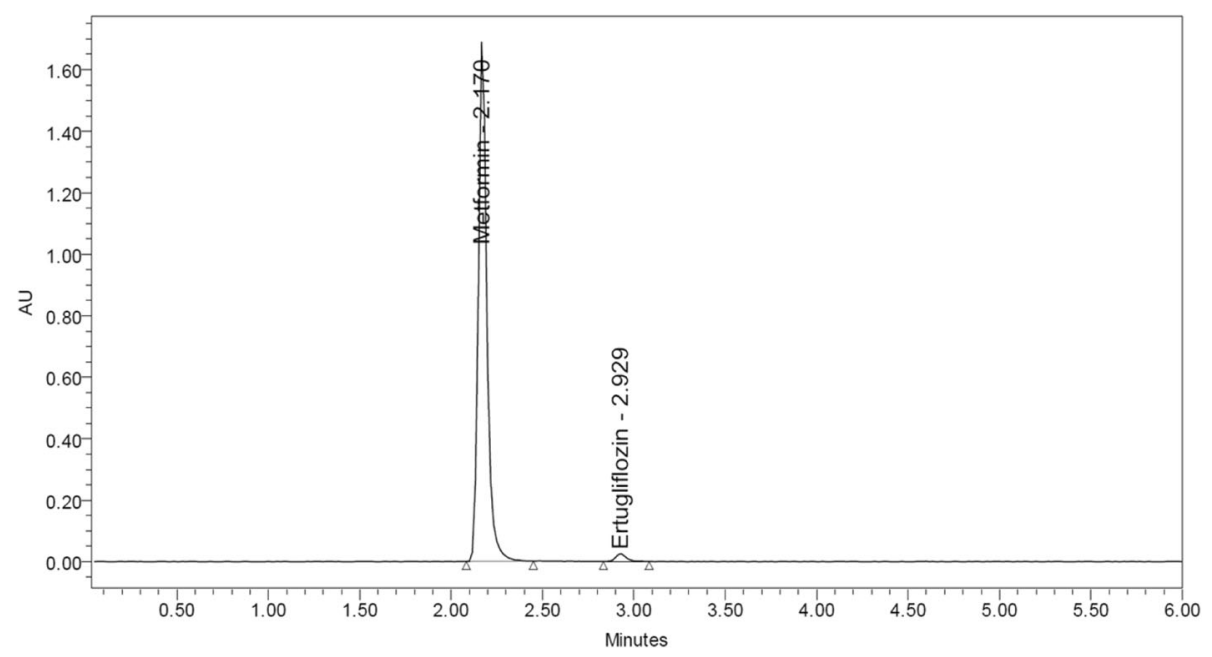

Fig. 4 Optimized chromatogram of ERTU and MET

\section{Linearity}

Linearity of the developed method was evaluated by injecting ERTU in the concentration range of $0.9375-$ $5.625 \mu \mathrm{g} / \mathrm{ml}$ and MET in the range of $62.5-375 \mu \mathrm{g} / \mathrm{ml}$. Calibration curve was constructed by plotting peak area on the $y$-axis against concentration $(\mu \mathrm{g} / \mathrm{ml})$ on the $x$ axis. The correlation coefficient of the calibration curve was calculated by using the method of least squares in MS Office Excel 2007.

\section{LOD and LOQ}

LOD and LOQ were calculated using the formulae based on the standard deviation of the $y$-intercept of regression lines and the slope of the calibration curve.

$$
\mathrm{LOD}=3.3 \times \frac{\sigma}{S} \quad \mathrm{LOQ}=10 \times \frac{\sigma}{S}
$$

where $\sigma$ is the standard deviation and $S$ is the slope of the curve.

\section{Stability of standard solution of ERTU and MET}

Stability of the standard solution of ERTU and MET was conducted by placing the solution in a volumetric flask at $30 \pm 2{ }^{\circ} \mathrm{C}$ for $24 \mathrm{~h}$. At three time points 0,12 , and 24 $\mathrm{h}$, about $10 \mu \mathrm{l}$ of the stored solution was injected into the column to calculate the percent (\%) assay difference of the drug.

\section{Robustness}

Robustness of the developed RP-HPLC method was evaluated by making minor changes in the flow rate $(0.9$ to $1.1 \mathrm{ml} / \mathrm{min}$ ), percentage of acetonitrile in the mobile phase $(30$ to $40 \%)$ and temperature $\left(25\right.$ to $\left.35^{\circ} \mathrm{C}\right)$. The parameters evaluated were \% RSD of peak areas, theoretical plates, tailing factor, and resolution.

\section{System suitability testing}

Suitability of the system was evaluated by injecting working standard solution into the column to evaluate parameters like \% RSD of peak areas, theoretical plates, tailing factor, and resolution in the optimized chromatographic conditions.

Table 2 Forced Degradation of ERTU and MET

\begin{tabular}{|c|c|c|c|c|c|c|c|c|}
\hline \multirow[t]{2}{*}{ Stressor } & \multicolumn{4}{|l|}{ ERTU } & \multicolumn{4}{|l|}{ MET } \\
\hline & Purity angle & Purity threshold & \% Assay & $\%$ Degraded & Purity angle & Purity threshold & \% Assay & $\%$ Degraded \\
\hline Acid & 1.493 & 1.966 & 92.45 & 7.55 & 1.448 & 1.801 & 92.29 & 7.71 \\
\hline Alkali & 1.766 & 2.146 & 94.56 & 5.44 & 1.402 & 1.752 & 93.07 & 6.93 \\
\hline Oxidative & 1.693 & 2.130 & 95.42 & 4.58 & 1.348 & 2.270 & 94.47 & 5.53 \\
\hline Thermal & 1.936 & 2.341 & 96.86 & 3.14 & 2.753 & 2.927 & 97.07 & 2.93 \\
\hline Photolytic & 1.659 & 2.009 & 98.30 & 1.70 & 2.489 & 2.786 & 98.21 & 1.79 \\
\hline Neutral & 1.780 & 2.134 & 98.98 & 1.02 & 2.358 & 2.915 & 99.10 & 0.90 \\
\hline
\end{tabular}


Table 3 Accuracy (\% recovery) of ERTU and MET

\begin{tabular}{|c|c|c|c|c|c|c|c|c|}
\hline \multicolumn{5}{|l|}{ ERTU } & \multicolumn{4}{|l|}{ MET } \\
\hline \multirow{2}{*}{$\begin{array}{l}\% \\
\text { Spiked } \\
\text { level }\end{array}$} & \multirow{2}{*}{$\begin{array}{l}\text { Fixed sample } \\
\text { concentration } \\
(\mu \mathrm{g} / \mathrm{ml})\end{array}$} & \multirow{2}{*}{$\begin{array}{l}\text { Amount } \\
\text { Spiked } \\
(\mu \mathrm{g} / \mathrm{ml})\end{array}$} & \multicolumn{2}{|l|}{ Statistical Analysis } & \multirow{2}{*}{$\begin{array}{l}\text { Fixed sample } \\
\text { concentration } \\
(\mu \mathrm{g} / \mathrm{ml})\end{array}$} & \multirow{2}{*}{$\begin{array}{l}\text { Amount } \\
\text { Spiked } \\
(\mu \mathrm{g} / \mathrm{ml})\end{array}$} & \multicolumn{2}{|c|}{ Statistical Analysis } \\
\hline & & & Mean $\%$ Recovery \pm SD & $\%$ RSD & & & $\begin{array}{l}\text { Mean \% } \\
\text { Recovery } \pm \\
\text { SD }\end{array}$ & $\begin{array}{l}\% \\
\text { RSD }\end{array}$ \\
\hline 80 & 3.75 & 3.0 & $100.04 \pm 0.306$ & 0.306 & 250 & 200 & $99.7 \pm 0.54$ & 0.54 \\
\hline 100 & 3.75 & 3.75 & $99.99 \pm 0.135$ & 0.135 & 250 & 250 & $99.91 \pm 0.57$ & 0.57 \\
\hline 120 & 3.75 & 4.50 & $99.87 \pm 0.64$ & 0.604 & 250 & 300 & $100.65 \pm 0.47$ & 0.47 \\
\hline
\end{tabular}

\section{Assay}

The working sample solution was injected six times into the column, and \% assay was calculated by using the formula:

$$
\begin{aligned}
\% \text { Assay }= & \frac{\text { Sample area }}{\text { Standard area }} \times \frac{\text { Dilution of standard }}{\text { Dilution of sample }} \\
& \times \frac{P}{100} \times \frac{\text { Avg.wt }}{\text { LC }} \times 100
\end{aligned}
$$

where Avg. wt is the average weight of tablets, $P$ is the percentage purity of working standard, and LC is the label claim of the drugs

\section{Results}

Based on the solubility studies, the diluent selected was HPLC grade water:ACN (1:1), ERTU being sparingly soluble in water and MET freely soluble in water.

\section{Method optimization}

Method was optimized by trial and error method to obtain a chromatogram with good resolution, acceptable number of theoretical plates, and tailing factor. To optimize the method, preliminary trial runs were performed by changing mobile phase and column type (Table 1). Buffer selected for the present analysis was $0.1 \%$ ortho-phosphoric acid, as ERTU (566 Da) and MET (165.62 Da) being regular samples with basic nature requiring the control of $\mathrm{pH}$ by the addition of buffer in the mobile phase. The $\mathrm{pH}$ of the buffer should be \pm 1.5 $\mathrm{U}$ of the $\mathrm{pKa}$ value to retain the drug in single state which avoids peak splitting [16]. pH of the buffer selected was 2.7 as the pKa of ERTU was 11.98 and MET was 12.33 to retain both the selected drugs in completely ionized state in order to avoid peak splitting.

PDA detector has an advantage of simultaneously collecting the chromatograms in the entire UV range during a single run [16]. When the drug samples were scanned between 200 and $400 \mathrm{~nm}$, the ideal $\lambda$ max was found to be $224 \mathrm{~nm}$. UV spectrum is shown in Fig. 3. C18 columns are rugged, highly retentive, and widely available [16]. Optimal separation and peak shapes were obtained on Kromasil C18 column with dimensions of $150 \mathrm{~mm} \times 4.6 \mathrm{~mm}, 5 \mu \mathrm{m}$ indicating that it was suitable for the simultaneous estimation of ERTU and MET. Theoretical plates are an important characteristic of the column which indicates the ability of the column to produce sharp, narrow peaks for achieving good resolution. Under optimized test conditions, a column with a length of $150 \mathrm{~mm}$ and a particle diameter of $5 \mu \mathrm{m}$ produces theoretical plates of $10,000-12,000$ [16]. In the optimized trial, the observed system suitability parameters were theoretical plates (11,025 (MET), 11,261 (ERTU)), tailing factor (1.2 (MET), 1.1 (ERTU)) and resolution of 7.7 for both the drugs reflecting that the selected column was ideal for the estimation of the drugs.

In the trial runs, for the ideal separation of the selected drugs, mixtures of solvents like methanol and acetonitrile with or without buffers $(0.1 \%$ ortho-phosphoric acid and $\mathrm{KH}_{2} \mathrm{PO}_{4}$ ) in different proportions were tried on C18 column. In the optimized method, the mobile phase selected was $0.1 \%$ ortho-phosphoric acid ( $\mathrm{pH} 2.7)$ :acetonitrile $(65: 35 \% v / v)$, as the resolution and peak shape of ERTU and MET were good with optimum system suitability parameters. The flow rate was optimized based on the peak resolution and minimal consumption of the mobile phase, and the flow rate selected was $1.0 \mathrm{ml} / \mathrm{min}$. MET and ERTU were eluted at $2.170 \mathrm{~min}$ and $2.929 \mathrm{~min}$ confirming that MET $(\log P-0.92)$ was more polar over

Table 4 Linearity of ERTU

\begin{tabular}{ll}
\hline Concentration $[x](\mu \mathrm{g} / \mathrm{ml})$ & Mean peak area* $[\mathrm{y}](\mathrm{AU})$ \\
\hline 0 & 0 \\
0.9375 & 24,802 \\
1.875 & 49,541 \\
2.8125 & 74,657 \\
3.75 & 99,130 \\
4.6875 & 125,714 \\
5.625 & 145,645 \\
Linear regression equation $(y=m x+c)$ & $y=26,223 x+460.9$ \\
Slope $(m)$ & 26,223 \\
Intercept $(c)$ & 460.9 \\
Correlation coefficient $\left(R^{2}\right)$ & 0.999
\end{tabular}

*Average of three determinations 
Table 5 Linearity of MET

\begin{tabular}{ll}
\hline Concentration $[x](\mu \mathrm{g} / \mathrm{ml})$ & Mean peak area* $[\mathrm{y}](\mathrm{AU})$ \\
\hline 0 & 0 \\
62.5 & $1,374,565$ \\
125 & $2,780,573$ \\
187.5 & $4,158,469$ \\
250 & $5,566,797$ \\
312.5 & $6,877,296$ \\
375 & $8,152,632$ \\
Linear regression equation $(y=m x+c)$ & $y=21,857 x+31,878$ \\
Slope $(m)$ & 21,857 \\
Intercept $(c)$ & 31,878 \\
Correlation coefficient $\left(R^{2}\right)$ & 0.999 \\
\hline
\end{tabular}

*Average of three determinations

ERTU ( $\log P$ 2.21). Optimized chromatogram is shown in Fig. 4.

The developed method was validated as per $\mathrm{ICH}$ guidelines. Good association was observed between the retention times of the standard and sample peaks confirming the drugs in the tablet were ERTU and MET. Additional peaks were absent in the chromatograms indicating no interference of excipients with the drugs at the retention times, and the developed method was specific for the simultaneous estimation of the drugs in tablet formulation.

The important part of validation of a stabilityindicating method is to assess the presence of impurities under the main analyte peak. The analyte peak should be checked for its purity/homogeneity, which is usually evaluated by determining the purity angle and purity threshold. According to the ICH Q2 (R1) guidelines, in forced degradation studies, purity threshold should be greater than purity angle and \% degradation should be less than 20 to consider the method as stable [12]. The developed method was specific and stable for the simultaneous estimation of the drugs. The \% degradation of ERTU and MET were $1.02-7.55$ and $0.90-7.71$, respectively. The co-elution of degradants with the drugs was absent. The purity threshold for both the drugs (1.9662.341 (ERTU), 1.752-2.927 (MET)) was found to be greater than the purity angle (1.493-1.936 (ERTU), 1.348-2.753 (MET)) in the presence of $2 \mathrm{~N} \mathrm{HCl}, 2 \mathrm{~N}$ $\mathrm{NaOH}, 20 \% v / v \mathrm{H}_{2} \mathrm{O}_{2}$ at $60 \pm 2{ }^{\circ} \mathrm{C}$ for $30 \mathrm{~min}$, in the oven at $105 \pm 2{ }^{\circ} \mathrm{C}$ for $6 \mathrm{~h}$, in the UV chamber for 7 days and in the presence of HPLC grade water at $60 \pm 2{ }^{\circ} \mathrm{C}$ for $30 \mathrm{~min}$.

In forced degradations studies, purity threshold was found to be greater than purity angle for both the drugs inferring the absence of co-elution of degradants with the drugs, and the analyte peaks were pure. Percent degradation of less than 10 for both the drugs demonstrates that the developed method was specific and stable (Table 2). Accuracy is presented in terms of \% recovery and should be 98-102 [12]. Accuracy was demonstrated at 80,100 , and $120 \%$ of the target concentration, and the percent recovery for ERTU was 99.27-100.60, and MET was 99.11-101.13 (Table 3) reflecting that the developed method was accurate. The \% RSD is used to express the precision of the method, and $\mathrm{ICH}$-stated limits are that \% RSD should be not more than 2.0 for intra-day precision and inter-day precision [12]. The \% RSD of intraday precision was 0.25 and 0.42 (Table 7) for ERTU and MET. \% RSD of inter-day precision was 0.70 and 0.56 (Table 7) for ERTU and MET implying that the deviation was less among repeated results and the developed method was more precise.

The linearity is expressed in terms of correlation coefficient $\left(\mathrm{R}^{2}\right)$ and should be not less than (NLT) 0.999 [12]. The developed method was found to be linear in the concentration range of $0.9375-5.625 \mu \mathrm{g} / \mathrm{ml}$ for ERTU (Table 4) and 62.5-375 $\mu \mathrm{g} / \mathrm{ml}$ for MET (Table 5)

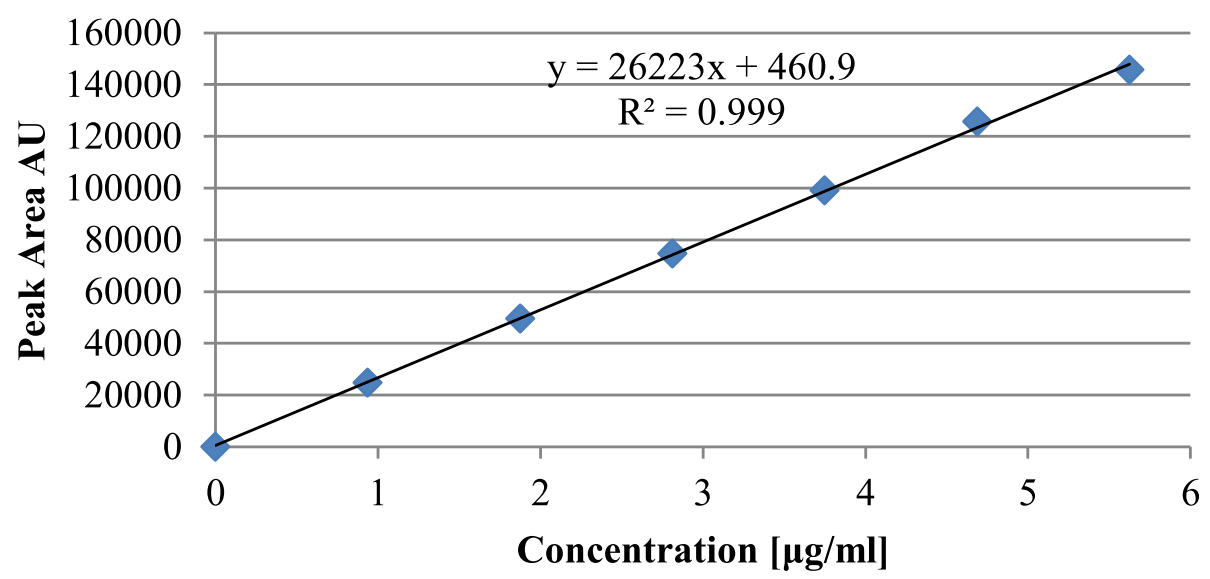

Fig. 5 Calibration curve of ERTU 


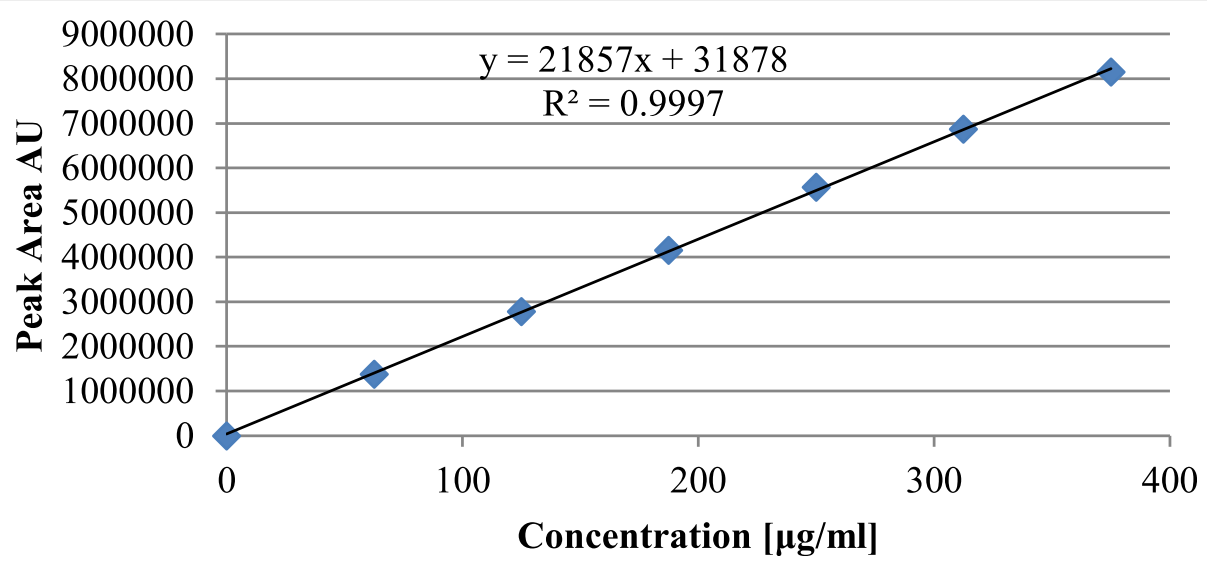

Fig. 6 Calibration curve of MET

with a correlation coefficient of 0.999 for both the drugs indicating the linear relationship between the peak area and concentration of the drugs (Figs. 5 and 6). LOD for ERTU and MET were $0.025 \mu \mathrm{g} / \mathrm{ml}$ and $0.87 \mu \mathrm{g} / \mathrm{ml}$ (Table 7) respectively indicating that the developed method was suitable for the estimation of $0.1 \mu \mathrm{g}$ of the drugs. LOQ for ERTU and MET were $0.076 \mu \mathrm{g} / \mathrm{ml}$ and $2.63 \mu \mathrm{g} / \mathrm{ml}$ (Table 7). The stability of standard solution is expressed in terms of \% assay difference, and it should be no more than (NMT) 2.0 [12]. In the present study, \% assay difference was 0.76 for $12 \mathrm{~h}$ and 1.74 for $24 \mathrm{~h}$ for ERTU and was 0.83 and 1.51 for MET (Table 7). The \% assay difference of ERTU and MET reflect that the solution was stable for $24 \mathrm{~h}$ at $30 \pm 2{ }^{\circ} \mathrm{C}$.

System suitability parameters are used for expressing the robustness of the method. To consider the method is robust, \% RSD should be less than 2.0, theoretical plates should be more than 2000, tailing factor should be less than 2.0, and resolution should be more than 2.0 [12]. The system suitability parameters observed were \% RSD 0.531-1.377 (ERTU), 0.382-1.293 (MET), theoretical plates 11,564-13,396 (ERTU), 9463-11,751 (MET), tailing factor 1.14-1.26 (ERTU), 1.14-1.33 (MET), and resolution of 6.78-9.2 for ERTU and MET reflecting that the developed method was robust for the simultaneous determination of ERTU and MET (Table 6). In the present study, the \% RSDs 0.531 (ERTU) and 0.382 (MET), theoretical plates 11,679 (ERTU) and 9947 (MET), tailing factors 1.23 (ERTU) and 1.25 (MET), and resolution of 7.21 for ERTU and MET indicate that the system was suitable for the simultaneous analysis of ERTU and MET (Table 7). On the application of the developed method to tablets, the mean amount of ERTU and MET present in the tablets were found to be $7.45 \pm$ $0.16 \mathrm{mg}$ and $497.4 \pm 0.97 \mathrm{mg}$ against the labeled claim of $7.5 \mathrm{mg}$ (ERTU) and $500 \mathrm{mg}$ (MET), reflecting that the method was suitable for the simultaneous estimation of ERTU and MET in tablet formulation (Table 7).

\section{Discussion}

The stability-indicating RP-HPLC method is an analytical procedure that is capable of discriminating between the major active pharmaceutical ingredients from any degradation/decomposition products formed under

Table 6 Robustness of ERTU and MET

\begin{tabular}{|c|c|c|c|c|c|c|c|c|}
\hline \multirow[t]{2}{*}{ Parameter } & \multirow{2}{*}{$\begin{array}{l}\text { Modified } \\
\text { condition }\end{array}$} & \multicolumn{2}{|c|}{ \% RSD of peak area (NMT $2.0 \%)$} & \multicolumn{2}{|c|}{ Theoretical plates* N (> 2000) } & \multicolumn{2}{|c|}{ Tailing factor* $(<2.0)$} & \multirow{2}{*}{$\begin{array}{l}\mathrm{Rs}^{*} \\
(> \\
2.0)\end{array}$} \\
\hline & & ERTU & MET & ERTU & MET & ERTU & MET & \\
\hline \multirow[t]{3}{*}{ Flow rate $(\mathrm{ml} / \mathrm{min})$} & 0.9 & 0.893 & 1.209 & 12,959 & 10,911 & 1.17 & 1.17 & 7.96 \\
\hline & 1.0 & 0.531 & 0.382 & 11,679 & 9947 & 1.23 & 1.33 & 7.21 \\
\hline & 1.1 & 0.949 & 1.113 & 11,564 & 9463 & 1.21 & 1.16 & 7.63 \\
\hline \multirow{3}{*}{$\begin{array}{l}\text { ACN ratio in mobile phase } \\
\text { Buffer: ACN }(\% \mathrm{v} / \mathrm{v})\end{array}$} & $70: 30$ & 1.377 & 1.039 & 11,949 & 11,751 & 1.26 & 1.15 & 9.2 \\
\hline & $65: 35$ & 0.531 & 0.382 & 11,679 & 9947 & 1.23 & 1.33 & 7.21 \\
\hline & $60: 40$ & 1.360 & 1.293 & 12,741 & 9485 & 1.22 & 1.14 & 6.78 \\
\hline \multirow[t]{3}{*}{ Temperature $\left({ }^{\circ} \mathrm{C}\right)$} & 25 & 0.912 & 1.278 & 13,396 & 9470 & 1.14 & 1.20 & 7.03 \\
\hline & 30 & 0.531 & 0.382 & 11,679 & 9947 & 1.23 & 1.33 & 7.21 \\
\hline & 35 & 0.574 & 0.993 & 13,396 & 9516 & 1.21 & 1.17 & 7.01 \\
\hline
\end{tabular}

* All the values were expressed as mean of six determinations 
Table 7 Summary of validation parameters of ERTU and MET

\begin{tabular}{|c|c|c|c|}
\hline \multirow[t]{2}{*}{ Parameter } & \multicolumn{2}{|l|}{ Results } & \multirow[t]{2}{*}{$\mathrm{ICH}$ limits } \\
\hline & MET & ERTU & \\
\hline Retention time (min) & 2.170 & 2.929 & - \\
\hline \multicolumn{4}{|l|}{ System suitability parameters } \\
\hline$\%$ RSD & 0.382 & 0.531 & NLT 2.0 \\
\hline Theoretical plates & 9947 & 11679 & MT 2000 \\
\hline Tailing factor & 1.25 & 1.23 & NMT 2.0 \\
\hline Range $(\mu \mathrm{g} / \mathrm{ml})$ & $62.5-375$ & $0.9375-5.625$ & - \\
\hline Linearity $\left(R^{2}\right)$ & 0.999 & 0.999 & NLT 0.999 \\
\hline$\%$ Recovery & $99.11-101.13$ & $99.27-100.60$ & $98-102$ \\
\hline \multicolumn{4}{|l|}{$\%$ RSD } \\
\hline Intra-day precision & 0.42 & 0.25 & NMT 1.0 \\
\hline Inter-day precision & 0.56 & 0.70 & NMT 2.0 \\
\hline LOD $(\mu \mathrm{g} / \mathrm{ml})$ & 0.87 & 0.025 & - \\
\hline LOQ ( $\mu \mathrm{g} / \mathrm{ml})$ & 2.63 & 0.076 & - \\
\hline$\%$ Assay difference at $24 \mathrm{~h}$ & 1.51 & 1.74 & NMT 2.0 \\
\hline \% Assay & 99.48 & 99.31 & - \\
\hline
\end{tabular}

defined storage conditions. Stability-indicating assay method development studies the effect of stressors on a drug which helps in understanding the stability of the drug during storage conditions and analysis. Few methods were reported for the simultaneous estimation of ERTU and MET by RP-HPLC. In the present method, MET and ERTU were eluted at 2.170 and $2.929 \mathrm{~min}$ with a resolution of 7.21 . The present method was developed using $0.1 \%$ ortho-phosphoric acid ( $\mathrm{pH}$ 2.7): ACN as the mobile phase. The developed method was found to be sensitive and costeffective with the reduced ratio of organic solvent in the mobile phase.

\section{Conclusion}

Improved stability-indicating RP-HPLC method was developed and validated for the simultaneous estimation of ertugliflozin and metformin. The present method was developed using $0.1 \%$ ortho-phosphoric acid $(\mathrm{pH} 2.7)$ : acetonitrile as the mobile phase. The method was found to be sensitive and cost-effective with the reduced ratio of organic solvent in the mobile phase, decrease in linearity range, LOD and LOQ, and retention times compared to the best method reported. The developed method could be suitable for routine analysis of the drugs in bulk and tablet formulation.

\section{Abbreviations}

ERTU: Ertugliflozin pidolate; MET: Metformin hydrochloride;

PTFE: Polytetrafluoroethylene; LOD: Limit of detection; LOQ: Limit of quantitation; \% RSD: Relative standard deviation; ACN: Acetonitrile; NMT: Not more than; NLT: Not less than; min: Minutes; MT: More than;

ICH: International Conference on Harmonization; Rs: Resolution; SD: Standard deviation; SGT-2: Sodium glucose co-transporter type-2; ${ }^{\circ} \mathrm{C}$ : Degree Celsius;

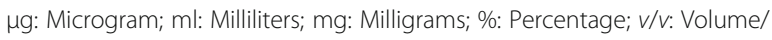
volume; RP: Reverse phase; HPLC: High-performance liquid chromatography

\section{Acknowledgements}

The authors are grateful to Ajanta Pharma, Mumbai and Laurus Labs, Hyderabad for providing the gift sample of ertugliflozin pidolate and metformin $\mathrm{HCl}$ to carry out the above research work.

\section{Authors' contributions}

The authors have read and approved the manuscript. SB and SK designed the study. SK performed the experiment and analyzed and reviewed the data. SB supervised the experiment, reviewed the data, and supported for writing the manuscript.

\section{Funding}

Not Applicable

Availability of data and materials

All data and materials are available upon request.

Ethics approval and consent to participate

Not Applicable

\section{Consent for publication}

Not Applicable

\section{Competing interests}

The authors declare that they have no competing interests.

Received: 9 May 2020 Accepted: 12 August 2020

Published online: 01 October 2020

\section{References}

1. International Diabetes Federation (2019): Statistics of diabetes mellitus. retrieved from idf.org/aboutdiabetes/what-is-diabetes/facts-figures.html.

2. Rang HP, Dale MM, Ritter JM, Flower RJ and Henderson G (2012): Rang and Dale's Pharmacology. Edinburgh, Churchill Livingstone, 7th Edn, pp 377-383.

3. Katzung BG, Masters SB, Trevor AJ (2015) Basic and clinical pharmacology. 13th Edn. McGraw Hill Medical, New York, pp 736-742

4. Das, SK, Elbein SC, (2006): The genetic basis of type 2 diabetes. Cell Science: 2(4):p.no.100-131. 
5. Goodman L, Gilman A, Brunton L, and Chabner B, Knollmann B (2011): Goodman and Gilman's the pharmacological basis of therapeutics. 12th Edn: New York, McGraw-Hill, pp 892-1266.

6. FDA Label: Merck \& Co. Inc. SEGLUROMET ${ }^{\text {TM }}$ (Ertugliflozin and Metformin hydrochloride) tablets, for oral use. Initial US Approval, (2017): Retrieved from https://www.accessdata.fda.gov/drugsatfda_docs/label/2017/209806 s000lbl.pdf.

7. Drug bank, Ertugliflozin: https://www.drugbank.ca/ salts/DBSALT002616

8. Drug bank, Metformin HCl https:/www.drugbank.ca/ salts/DBSALT000114

9. Mashru R, Damor D, Mittal K, Patel B (2015) Method development and validation of simultaneous estimation of cilostazol and telmisartan. Journal of Pharmaceutical Analysis 4(3):41-48

10. Venkateswara Rao P, Lakshmana Rao A, Prasad SVUM (2019) Development and validation of new stability indicating reversed-phase high-performance liquid chromatography method for simultaneous determination of metformin hydrochloride and ertugliflozin in bulk and pharmaceutical dosage form. Asian J Pharm Clin Res 12(1):235-240

11. Nizami T, Shrivastava B, Sharma P (2018) Analytical method development and validation for simultaneous estimation of ertugliflozin and metformin in tablet dosage form by RP-HPLC method. International Journal of Pharmacy and Life Sciences 9(7):5854-5859

12. ICH Harmonized Triplicate Guideline (2005): Validation of analytical procedures: text and methodology Q2 (R1), ICH Steering Committee, Step 4 of ICH process, Retrieved form https://database.ich.org/sites/default/files/ Q2_R1_Guideline.pdf.

13. Ahuja S, Scypinski S (2013) Handbook of modern pharmaceutical analysis. Elsevier, Massachusetts, pp 4-449

14. International Conference on Harmonisation of technical requirements for registration of pharmaceuticals for human use, ICH Harmonised tripartite guideline (2003): stability testing of new drug substances and products Q1A (R2), Retrieved form https://database.ich.org/sites/default/files/Q1A\%28R2\%2 9\%20Step4.pdf.

15. International Conference on Harmonisation of technical requirements for registration of pharmaceuticals for human use, $\mathrm{ICH}$ Harmonised tripartite guideline (1996): Stability testing: photostability testing of new drug substances and products Q1B, Retrieved form https://database.ich.org/sites/ default/files/ Q1B Guideline.pdf.

16. Snyder LR, Kirkland JJ and Glajch JL (1997): Practical HPLC method development. John Wiley and Sons: 1-438.

\section{Publisher's Note}

Springer Nature remains neutral with regard to jurisdictional claims in published maps and institutional affiliations.

\section{Submit your manuscript to a SpringerOpen ${ }^{\circ}$ journal and benefit from:}

- Convenient online submission

- Rigorous peer review

- Open access: articles freely available online

High visibility within the field

- Retaining the copyright to your article

Submit your next manuscript at $\boldsymbol{\nabla}$ springeropen.com 